\title{
Bridging the Yield Gap in Rice Production by Using Leaf Color Chart for Nitrogen Management
}

\author{
Naeem Ahmad, Ahmad Zada, Muhammad Junaid, and Akhtar Ali \\ Agricultural Research Institute, P.O. Box 22, Mingora-Swat, Saidu Sharif, Khyber Pakhtunkhwa, Pakistan \\ Correspondence should be addressed to Muhammad Junaid; johnaidmj@gmail.com
}

Received 17 September 2015; Revised 5 January 2016; Accepted 13 January 2016

Academic Editor: Guang S. Zhou

Copyright (C) 2016 Naeem Ahmad et al. This is an open access article distributed under the Creative Commons Attribution License, which permits unrestricted use, distribution, and reproduction in any medium, provided the original work is properly cited.

\begin{abstract}
An experiment was conducted to optimize nitrogen fertilizer application for rice genotypes with the help of leaf color chart practice under agroclimatic conditions of Malakand division. The experiment was designed in RCB having split plot arrangement. Main plots consisted of rice genotypes, while subplots consisted of various doses of nitrogen. All the recorded parameters were significantly affected by the various $\mathrm{N}$ doses. In all treatments $\mathrm{N}$ application according to LCC management practice produced maximum tillers/hill, plant height, straw, and paddy yield as compared to $\mathrm{N}$ application according to recommended dose and farmer's practice. This adequate supply of $\mathrm{N}$ fertilizer according to LCC management practice resulted in positive response of $\mathrm{N}$ fertilizer on the crop and also provided best fertilizer management techniques. Moreover, the interaction between rice genotypes and LCC management practice was the best for all the recorded parameters. The outcome results of the experiment provided an economic package to the farmers in application of $\mathrm{N}$ fertilizer on the basis of leaf color chart management practice.
\end{abstract}

\section{Introduction}

Rice (Oryza sativa L.) being the most important cereal of the world fulfills one-third of food requirement of the world population. It provides some 700 calories per person, mostly residing in developing countries [1]. According to International Rice Research Institute (IRRI) 800 million tons of rice will be required in 2025 [2].

Pakistan is blessed with multitude of agroclimatic conditions for growing several types of rice, that is, aromatic long fine grain, medium grain, and round grain Japonica type. Rice is a high value cash crop and also a major export item. Pakistan annually exports about 2.5 to 3.0 million tons of rice which is about 9-10 percent of the world rice trade. The exports of Basmati and coarse rice are made mainly to Southeast, South Asia, Europe, and Africa markets. Coupled with production, harvesting, and postharvest operations, variety is considered the most important determinant of market quality. Presently a large number of rice varieties are grown in different rice growing zone of Pakistan and our breeding programs are continually striving to refine and improve the genetic characteristics that influence quality and yield to tailor the most desirable varieties for local as well as foreign market [3].

Rice is an important kharif crop of Pakistan, ranking second to wheat as a food staple. Rice has gradually moved to occupy a predominant position in the agricultural economy of Pakistan. Presently rice is grown on an area of 2.28 million hectares and is the country's third largest crop in terms of area. Traditionally, rice cultivation has been concentrated in the Khyber Pakhtunkhwa province, central Punjab, and the North Western districts of Sindh. In major rice growing belts, rural economy and prosperity have now become considerably dependent on rice and historically a number of small markets and towns have developed and flourished along the trading and processing of rice. In Khyber Pakhtunkhwa, rice cultivation stands next to wheat and maize and is characterized by being grown under two different agroclimatic conditions, that is, the plains and the upper mountainous valleys [4].

Adequate nutrient supply plays a vital role in soil and crop management system. Knowing the required nutrients for all stages of growth and understanding the soil's ability to supply those needed nutrients are critical to profitable crop production [5]. Increased fertilizer inputs, especially $\mathrm{N}$ 
fertilizer, results in significant increase in rice crop production [6]. Farmers generally apply fertilizer $\mathrm{N}$ in several split applications, but the number of splits, amount of $\mathrm{N}$ applied per split, and the time of applications vary substantially. The apparent flexibility of rice farmers in adjusting the time and amount of fertilizer application offers potential to synchronize nitrogen application with the real-time demand of the rice crop [7]. Farmers generally apply too much $\mathrm{N}$ (and little $\mathrm{P}$ and $\mathrm{K}$ and other nutrients) that results in high pest and disease incidence and serious lodging. The consequence of high $\mathrm{N}$ application is associated with the high pesticide use to control pests, more expenditure on pesticides, and reduced yield and poor grain quality due to lodging [8]. Site specific nitrogen management has the potential to increase fertilizer use efficiency as well as grain yield in the farmers' fields [9]. Precise application of $\mathrm{N}$ fertilizer based on plant need and location in the field greatly improves fertilizer use efficiency in rice.

The optimum use of $\mathrm{N}$ can be achieved by matching $\mathrm{N}$ supply with crop demand. Farmers generally use leaf color as a visual and subjective indicator of the rice crop's nitrogen status and need for $\mathrm{N}$ fertilizer application. Leaf color intensity is directly related to leaf chlorophyll content which, in turn, is related to leaf $\mathrm{N}$ status. The concept is based on results that show a close link between leaf chlorophyll content and leaf $\mathrm{N}$ content [8]. One of the recently introduced $\mathrm{N}$ management approach was estimating the leaf $\mathrm{N}$ concentration by the measurement of leaf greenness. Among the different tools available to measure the leaf greenness, the nondestructive measurement of leaf green color intensity using leaf color charts (LCC) is gaining importance [10].

The LCC determines the suitable time of $\mathrm{N}$ application to the rice crop by measuring leaf color intensity which is related to leaf $\mathrm{N}$ status; in addition, it also helps in $\mathrm{N}$ use efficiency, thus resulting in reasonably high yield; identification of correct threshold values of the LCC is essential as they differ according to location, season, variety, and rice ecosystem. The experiment was conducted with the main objectives to compare farmers and standard nitrogen fertilizer use practices with the LCC based method, to improve understanding of farmer's fertilizer management decisions, to increase nitrogen use efficiency, and to observe the effect of LCC use on minimizing lodging incidence.

\section{Materials and Methods}

An experiment entitled "Bridging the yield gap in rice production by using leaf color chart (LCC) for nitrogen management" was conducted during kharif 2011 and repeated during the year 2012 at the Agricultural Research Institute, Mingora, Swat. The experiment was laid out in Randomized Complete Block design (RCB) with split plot arrangement, having three replications. Rice genotypes were assigned to main plots, whereas the treatments were allotted to the subplots. Nursery was sown in the 2nd week of May and transplanted in the age of thirty days. Before transplanting, the field was thoroughly prepared. Water was applied to the field, for puddling.
TABLE 1: Details of the rice genotypes and management practices combinations.

\begin{tabular}{lc}
\hline & Varieties \\
V1 & Swat-1 \\
V2 & Basmati 385 \\
V3 & JP5 \\
\hline & \\
M1 & Management practices \\
M2 & Farmers practice \\
M3 & Leaf color chart practice \\
\hline
\end{tabular}

TABLE 2: Effects of different nitrogen management practices on tillers/hill.

\begin{tabular}{lcccc}
\hline \multirow{2}{*}{ S. number } & Treatments & \multicolumn{2}{c}{ Years } & Mean over \\
\hline 1 & 2011 & 2012 & the years \\
\hline 2 & $\begin{array}{c}\text { Farmer practice } \\
(\mathrm{M} 1)\end{array}$ & $14.7 \mathrm{~B}$ & $13.3 \mathrm{~B}$ & 14.0 \\
3 & $\begin{array}{c}\text { Leaf color chart } \\
\text { practice (M2) }\end{array}$ & $17.4 \mathrm{~A}$ & $16.0 \mathrm{~A}$ & 16.7 \\
& $\begin{array}{c}\text { Recommended } \\
\text { practice (M3) }\end{array}$ & $15.4 \mathrm{~B}$ & $13.9 \mathrm{AB}$ & 14.6 \\
LSD $(P \leq 0.05)$ & & 1.61 & 2.26 &
\end{tabular}

Means sharing the same letters are nonsignificant to each other at $5 \%$ level of probability.

Before conducting the trial the experimental site was tested for NPK levels. The amount of available nitrogen was $26.25 \mathrm{ppm}$, while phosphorous level was $9.89 \mathrm{ppm}$, and potash was $50.0 \mathrm{ppm}$ that was the lower level of these essential elements (Source: Soil Fertility Section. ARI, Mingora, Swat). After soil analysis well puddled field was supplied with nitrogen according to recommended dose of NPK, 120, 60, and $40 \mathrm{~kg} \mathrm{ha}^{-1}$, farmer's practice where NPK was applied $@ 115,60$, and $40 \mathrm{~kg} \mathrm{ha}^{-1}$, and in accordance to the leaf color chart. $\mathrm{N}$ fertilizer was applied in split doses (1/2 basal-1/2 mid tillering) in farmer practice and recommended practice. In the LCC practice basal dose was applied to all the three varieties@50 $\mathrm{kg} \mathrm{N} \mathrm{ha}^{-1}$. Data was recorded on leaf color chart with an interval of ten days, starting from two weeks after transplantation up to flower initiation. Generally, leaf color chart value for semidwarf high yielding rice varieties is 4.0 ; if the average value fell below 4.0, $\mathrm{N}$ fertilizer was top dressed $@ 30 \mathrm{~kg} \mathrm{ha}^{-1}$ to correct the $\mathrm{N}$ deficiency.

Row to row and plant to plant distance of $20 \mathrm{~cm}$ was maintained in a plot size of $25 \mathrm{~m}^{2}$. The recorded data was subjected to statistical analysis and treatment means were compared using critical value for comparison, through statistical software, Statistics-8.1 package. The details of rice genotypes and treatment combinations are presented in the Table 1.

\section{Results and Discussions}

3.1. Tillers/Hill. Data regarding effect of different nitrogen management practices on tillers/hill is presented in Table 2. 
TABLE 3: Effects of interaction between different rice genotypes (V) and nitrogen management practices $(\mathrm{M})$ on tillers/hill.

\begin{tabular}{lcccc}
\hline \multirow{2}{*}{ S. number } & Treatments & \multicolumn{2}{c}{ Years } & $\begin{array}{c}\text { Mean over } \\
\text { the years }\end{array}$ \\
\hline 1 & V1 $\times \mathrm{M} 1$ & $\mathbf{1 4 . 3}$ & 13.7 & 14.0 \\
2 & $\mathrm{~V} 1 \times \mathrm{M} 2$ & 17.3 & $\mathbf{1 7 . 3}$ & $\mathbf{1 7 . 3}$ \\
3 & $\mathrm{~V} 1 \times \mathrm{M} 3$ & 15.0 & 14.3 & 14.6 \\
4 & $\mathrm{~V} 2 \times \mathrm{M} 1$ & 15.7 & 14.3 & 15.0 \\
5 & $\mathrm{~V} 2 \times \mathrm{M} 2$ & $\mathbf{1 8 . 3}$ & 16.0 & 17.1 \\
6 & $\mathrm{~V} 2 \times \mathrm{M} 3$ & 17.0 & 16.0 & 16.5 \\
7 & $\mathrm{~V} 3 \times \mathrm{M} 1$ & $\mathbf{1 3 . 7}$ & 12.0 & $\mathbf{1 2 . 8}$ \\
8 & $\mathrm{~V} 3 \times \mathrm{M} 2$ & 16.7 & 14.7 & 15.7 \\
9 & $\mathrm{~V} 3 \times \mathrm{M} 3$ & $\mathbf{1 4 . 7}$ & $\mathbf{1 1 . 3}$ & 13.0 \\
LSD $(P \leq 0.05)$ & & N.S. & N.S. & \\
\hline
\end{tabular}

Means sharing the same letters are nonsignificant to each other at $5 \%$ level of probability.

It is evident from the data recorded that, during the year 2011, maximum tillers/hill (17.4) were observed for leaf color chart practice (M2) where nitrogen was applied @ $93 \mathrm{~kg} \mathrm{ha}^{-1}$, while minimum tillers/hill (14.7) were recorded for farmer practice where nitrogen was applied @115 $\mathrm{kg} \mathrm{ha}^{-1}$. The same trend was noticed during the year 2012, where maximum (16.0) tillers/hill were recorded for leaf color chart practice (M2), followed by recommended management practice (M3), where 13.9 tillers/hill were recorded. The lowest (13.3) tillers/hill were recorded in farmer practice (M1) where nitrogen was applied @115 $\mathrm{kg} \mathrm{ha}^{-1}$. It is evident from the data recorded during two years that plants in the leaf color chart management practice (M2) produced maximum tillers/hill. Our results were in line with the study of [11] who noted that soil application of $90 \mathrm{~kg} \mathrm{~N} \mathrm{ha}^{-1}$ significantly produced higher number of tillers than the control treatment.

The interaction between rice varieties and nitrogen management practices was nonsignificant (Table 3 ). Moreover, from the average tillers/hill worked out for two years, it was noticed that maximum tillers/hill (17.3) were recorded for treatment $(\mathrm{V} 1 \times \mathrm{M} 2)$ (i.e., variety Swat-1 had maximum tillers/hill with leaf color chart management practice (M2)), whereas minimum tillers/hill were recorded for treatment $(\mathrm{V} 3 \times \mathrm{M} 1)$ (i.e., variety JP5 with farmers nitrogen management practice (M1)).

3.2. Plant Height $(\mathrm{cm})$. Data about effect of different nitrogen management practices on plant height is presented in Table 4. It can be noticed from recorded data that, during the year 2011, maximum plant height $(133.1 \mathrm{~cm})$ was observed for leaf color chart practice (M2), while minimum plant height $(127.7 \mathrm{~cm})$ was observed for farmer practice (M1). The same trend was noticed during the year 2012, where maximum $(127.8 \mathrm{~cm})$ plant height was recorded in LCC practice of nitrogen application (M2), followed by farmer practice (M1) with minimum plant height of $122.8 \mathrm{~cm}$. Average data of two years showed that maximum plant height $(130.4 \mathrm{~cm})$ was recorded in the leaf color chart practice (M2). N fertilization amount
TABLE 4: Effects of different nitrogen management practices on plant height $(\mathrm{cm})$.

\begin{tabular}{lcccc}
\hline S. number & Treatments & \multicolumn{2}{c}{ Years } & $\begin{array}{c}\text { Mean over } \\
\text { the years }\end{array}$ \\
\hline 1 & $\begin{array}{c}\text { Farmer practice } \\
(\mathrm{M} 1)\end{array}$ & $127.7 \mathrm{~B}$ & $122.8 \mathrm{~B}$ & 125.2 \\
2 & $\begin{array}{c}\text { Leaf color chart } \\
\text { practice (M2) }\end{array}$ & $133.1 \mathrm{~A}$ & $127.8 \mathrm{~A}$ & 130.4 \\
3 & $\begin{array}{c}\text { Recommended } \\
\text { practice (M3) }\end{array}$ & $129.2 \mathrm{AB}$ & $124.8 \mathrm{AB}$ & 127.0 \\
LSD $(P \leq 0.05)$ & & 3.96 & 3.51 & \\
\hline
\end{tabular}

Means sharing the same letters are nonsignificant to each other at $5 \%$ level of probability.

TABLE 5: Effects of interaction between different rice genotypes (V) and nitrogen management practices $(\mathrm{M})$ on plant height $(\mathrm{cm})$.

\begin{tabular}{lcccc}
\hline \multirow{2}{*}{ S. number } & Treatments & \multicolumn{2}{c}{ Years } & Mean over \\
& & 2011 & 2012 & the years \\
\hline 1 & V1 $\times \mathrm{M} 1$ & 122.0 & 115.0 & 118.5 \\
2 & $\mathrm{~V} 1 \times \mathrm{M} 2$ & 127.7 & 121.3 & 124.5 \\
3 & $\mathrm{~V} 1 \times \mathrm{M} 3$ & 123.0 & 116.7 & 119.8 \\
4 & $\mathrm{~V} 2 \times \mathrm{M} 1$ & 127.0 & 122.7 & 124.8 \\
5 & $\mathrm{~V} 2 \times \mathrm{M} 2$ & 132.0 & 125.7 & 128.8 \\
6 & $\mathrm{~V} 2 \times \mathrm{M} 3$ & 130.3 & 124.0 & 127.1 \\
7 & $\mathrm{~V} 3 \times \mathrm{M} 1$ & 134.0 & 130.7 & 132.3 \\
8 & $\mathrm{~V} 3 \times \mathrm{M} 2$ & 139.7 & 136.3 & 138.0 \\
9 & $\mathrm{~V} 3 \times \mathrm{M} 3$ & 134.3 & 133.7 & 134.0 \\
LSD value at $(P \leq 0.05)$ & & N.S. & N.S. & \\
\hline
\end{tabular}

Means sharing the same letters are nonsignificant to each other at $5 \%$ level of probability.

had an important role in improving morphophysiological characteristics of rice and $\mathrm{N}$ could increase rice leaves and roots growth to prepare an appropriate Leaf Area Index (LAI) to obtain most plant height and grain yield [1]. Moreover, application of $\mathrm{N}$ in splits according to the plant needs in the LCC practice might be the reason for better rice growth parameters [12].

Nonsignificant interaction was observed among different rice varieties and nitrogen management practices for plant height (Table 5). However, it is evident from average data of two years that highest plant height $(138 \mathrm{~cm})$ was found for the treatment $(\mathrm{V} 3 \times \mathrm{M} 2)$ (i.e., variety JP5 produced maximum plant height with leaf color chart management practice (M2)), while minimum plant height $(118.5 \mathrm{~cm})$ was recorded for treatment $(\mathrm{V} 1 \times \mathrm{M} 1)$ (i.e., variety Swat-1 with farmers practice (M1)).

3.3. Straw Yield $\left(t h a^{-1}\right)$. Straw yield for effect of different nitrogen management practices is presented in Table 6. It is evident from the data recorded that, during the year 2011, maximum straw yield $\left(21.2 \mathrm{tha}^{-1}\right)$ was observed for leaf color chart practice (M2), while minimum straw yield $\left(19.2 \mathrm{tha}^{-1}\right)$ was recorded for farmer practice (M1). The same 
TABLE 6: Effects of different nitrogen management practices on straw yield $\left(\mathrm{tha}^{-1}\right)$.

\begin{tabular}{|c|c|c|c|c|}
\hline \multirow{2}{*}{ S. number } & \multirow{2}{*}{ Treatments } & \multicolumn{2}{|c|}{ Years } & \multirow{2}{*}{$\begin{array}{c}\text { Mean over } \\
\text { the years }\end{array}$} \\
\hline & & 2011 & 2012 & \\
\hline 1 & $\begin{array}{l}\text { Farmer practice } \\
\text { (M1) }\end{array}$ & $19.2 \mathrm{~B}$ & $16.9 \mathrm{~B}$ & 18.0 \\
\hline 2 & $\begin{array}{c}\text { Leaf color chart } \\
\text { practice (M2) }\end{array}$ & $21.2 \mathrm{~A}$ & $18.8 \mathrm{~A}$ & 20.0 \\
\hline 3 & $\begin{array}{c}\text { Recommended } \\
\text { practice (M3) }\end{array}$ & $20.2 \mathrm{AB}$ & $17.9 \mathrm{AB}$ & 19.0 \\
\hline $\operatorname{LSD}(P \leq 0.05)$ & & 1.42 & 2.06 & \\
\hline
\end{tabular}

Means sharing the same letters are nonsignificant to each other at $5 \%$ level of probability.

TABLE 7: Effects of interaction between different rice genotypes (V) and nitrogen management practices $(\mathrm{M})$ on straw yield $\left(\mathrm{t} \mathrm{ha}^{-1}\right)$.

\begin{tabular}{lcccc}
\hline \multirow{2}{*}{ S. number } & \multirow{2}{*}{ Treatments } & \multicolumn{2}{c}{ Years } & Mean over \\
& & 2011 & 2012 & the years \\
\hline 1 & $\mathrm{~V} 1 \times \mathrm{M} 1$ & 16.7 & $15.5 \mathrm{D}$ & 16.10 \\
2 & $\mathrm{~V} 1 \times \mathrm{M} 2$ & 16.7 & $17.2 \mathrm{D}$ & 16.95 \\
3 & $\mathrm{~V} 1 \times \mathrm{M} 3$ & 17.1 & $16.1 \mathrm{D}$ & 16.60 \\
4 & $\mathrm{~V} 2 \times \mathrm{M} 1$ & 20.5 & $16.4 \mathrm{C}$ & 18.45 \\
5 & $\mathrm{~V} 2 \times \mathrm{M} 2$ & 24.7 & $18.6 \mathrm{~A}$ & 21.65 \\
6 & $\mathrm{~V} 2 \times \mathrm{M} 3$ & 21.9 & $18.0 \mathrm{~B}$ & 19.95 \\
7 & $\mathrm{~V} 3 \times \mathrm{M} 1$ & 20.3 & $18.8 \mathrm{C}$ & 19.55 \\
8 & $\mathrm{~V} 3 \times \mathrm{M} 2$ & 22.1 & $20.7 \mathrm{~B}$ & 21.40 \\
9 & $\mathrm{~V} 3 \times \mathrm{M} 3$ & 21.4 & $19.5 \mathrm{BC}$ & 20.40 \\
LSD value at $(P \leq 0.05)$ & & N.S. & 1.42 & \\
\hline
\end{tabular}

Means sharing the same letters are nonsignificant to each other at $5 \%$ level of probability.

trend was noticed during the year 2012, where maximum $\left(18.8 \mathrm{tha}^{-1}\right)$ straw yield was recorded in (M2), followed by recommended management practice (M3), where $17.9 \mathrm{tha}^{-1}$ straw yield was recorded. The lowest $\left(16.9 \mathrm{tha}^{-1}\right)$ straw yield was recorded in farmer practice (M1) where nitrogen was applied @115 $\mathrm{kgha}^{-1}$. It is evident from the data recorded during two years that plants in the leaf color chart management practice (M2) produced maximum straw yield $20 \mathrm{tha}^{-1}$. Similarly, [11] founded that the grain yield, straw yield, and dry matter production of rice were significantly influenced by the $\mathrm{N}$ application and observed higher straw yield and grain yield than the other treatments.

Data regarding interaction between different varieties and nitrogen management practices showed nonsignificant trend during 2011 while significant differences for straw yield were found in 2012 (Table 7). Averaged straw yield for both years was maximum $\left(21.65 \mathrm{t} \mathrm{ha}^{-1}\right)$ for the treatment $(\mathrm{V} 2 \times \mathrm{M} 2)$ (i.e., variety Basmati 385 had maximum straw yield with leaf color chart management practice), while minimum straw yield $\left(16.1\right.$ t ha $\left.^{-1}\right)$ was recorded for treatment $(\mathrm{V} 1 \times \mathrm{M} 1)$ (i.e., variety Swat-1 with farmers practice received nitrogen according to farmers practice).
TABLE 8: Effects of different nitrogen management practices on paddy yield $\left(\mathrm{tha}^{-1}\right)$.

\begin{tabular}{lcccc}
\hline S. number & Treatments & \multicolumn{2}{c}{ Years } & Mean over \\
& 2011 & 2012 & the years \\
\hline 1 & $\begin{array}{c}\text { Farmer } \\
\text { practice (M1) } \\
\text { Leaf color } \\
\text { chart practice } \\
(\mathrm{M} 2)\end{array}$ & $5.8 \mathrm{~B}$ & $5.3 \mathrm{~B}$ & 5.55 \\
2 & $\begin{array}{c}\text { Recommended } \\
\text { practice (M3) }\end{array}$ & $5.5 \mathrm{~B}$ & $5.3 \mathrm{~B}$ & 5.40 \\
$\mathrm{LSD}(P \leq 0.05)$ & 0.60 & 0.42 & \\
\hline
\end{tabular}

Means sharing the same letters are nonsignificant to each other at $5 \%$ level of probability.

3.4. Paddy Yield $\left(t h a^{-1}\right)$. Data regarding effect of different nitrogen management practices on paddy yield is presented in Table 8. It is clear from recorded data that, during the year 2011, maximum paddy yield $\left(6.6 \mathrm{tha}^{-1}\right)$ was observed for leaf color chart practice (M2), while minimum paddy yield $\left(5.5 \mathrm{tha}^{-1}\right)$ was observed for recommended practice (M3). The trend was similar in the year 2012 findings, where maximum $\left(5.7 \mathrm{tha}^{-1}\right)$ paddy yield was recorded in the leaf color chart management practice (M2), followed by the farmer and recommended practice (M1 \& M3) with minimum paddy yield of $5.3 \mathrm{tha}^{-1}$ each. The averaged data of two years showed that maximum paddy yield $\left(6.15 \mathrm{tha}^{-1}\right)$ was recorded in the leaf color chart practice (M2). $\mathrm{N}$ fertilizer is a major essential plant nutrient and key input for an increasing rice crop yield as supported by [13]. Nitrogen contributes to carbohydrates accumulation in culms and leaf sheathes during the preheading stage and in the grain during the ripening stage of rice. Our results were also in agreement with [11] who found that the grain yield of rice was considerably affected by the $\mathrm{N}$ application and detected higher grain yield than the other treatments. The rate and timing of $\mathrm{N}$ application are critical for optimum rice grain yield [14].

The interaction between different varieties and nitrogen management practices for paddy yield was significant for the year 2011 and remained nonsignificant for year 2012 (Table 9). It is evident from averaged data of two years that highest paddy yield $\left(6.85 \mathrm{tha}^{-1}\right)$ was noted in two treatments; that is, $(\mathrm{V} 2 \times \mathrm{M} 2)$ and $(\mathrm{V} 3 \times \mathrm{M} 2)$ meant that both varieties Basmati 385 (V2) and JP5 (V3) produced maximum paddy yield with leaf color chart management practice where nitrogen was applied @93 $\mathrm{kg} \mathrm{ha}^{-1}$. However, minimum paddy yield $\left(4.05 \mathrm{tha}^{-1}\right)$ was recorded for treatment $(\mathrm{V} 1 \times \mathrm{M} 3)$, that is, variety Swat-1 with recommended nitrogen management practice where nitrogen was applied @120 $\mathrm{kg} \mathrm{ha}^{-1}$. $\mathrm{N}$ fertilization reflected an important role in betterment of morphophysiological traits of rice and $\mathrm{N}$ could increase rice leaves and roots growth to support an appropriate Leaf Area Index (LAI) in different rice varieties to obtain higher grain yield [1]. The use of LCC in rice field and split application N fertilizer based on LCC values can reduce the used nitrogen fertilizer [15]. The deep placement of urea, split $\mathrm{N}$ application, 
TABLE 9: Effects of interaction between different rice genotypes (V) and nitrogen management practices $(\mathrm{M})$ on paddy yield $\left(\mathrm{t} \mathrm{ha}^{-1}\right)$.

\begin{tabular}{lcccc}
\hline \multirow{2}{*}{ S. number } & Treatments & \multicolumn{2}{c}{ Years } & $\begin{array}{c}\text { Mean over } \\
\text { the years }\end{array}$ \\
\hline 1 & V1 $\times \mathrm{M} 1$ & $4.8 \mathrm{D}$ & 3.7 & 4.25 \\
2 & $\mathrm{~V} 1 \times \mathrm{M} 2$ & $5.6 \mathrm{C}$ & 4.0 & 4.80 \\
3 & $\mathrm{~V} 1 \times \mathrm{M} 3$ & $4.7 \mathrm{D}$ & 3.4 & 4.05 \\
4 & $\mathrm{~V} 2 \times \mathrm{M} 1$ & $6.3 \mathrm{~B}$ & 6.4 & 6.35 \\
5 & $\mathrm{~V} 2 \times \mathrm{M} 2$ & $6.9 \mathrm{AB}$ & 6.8 & 6.85 \\
6 & $\mathrm{~V} 2 \times \mathrm{M} 3$ & $6.3 \mathrm{~B}$ & 6.4 & 6.35 \\
7 & $\mathrm{~V} 3 \times \mathrm{M} 1$ & $6.3 \mathrm{~B}$ & 5.8 & 6.05 \\
8 & $\mathrm{~V} 3 \times \mathrm{M} 2$ & $7.3 \mathrm{~A}$ & 6.4 & 6.85 \\
9 & $\mathrm{~V} 3 \times \mathrm{M} 3$ & $5.4 \mathrm{C}$ & 6.1 & 5.75 \\
LSD value at $(P \leq 0.05)$ & & 0.60 & N.S. & \\
\hline
\end{tabular}

Means sharing the same letters are nonsignificant to each other at $5 \%$ level of probability.

the chlorophyll meter, and leaf color chart techniques are $\mathrm{N}$ management strategies that could improve fertilizer use efficiency in rice [16]. The LCC determines the right time of $\mathrm{N}$ application to the rice crop by measuring leaf color intensity which is related to leaf $\mathrm{N}$ status. In addition, it also helps to optimize $\mathrm{N}$ use at reasonably high yield levels, regardless of whether $\mathrm{N}$ source identifying the correct threshold values of the LCC is essential as they differ according to location, season variety, and rice ecosystem [17].

\section{Conclusions}

From the above findings it is clear that rice variety Basmati 385 is a high yielding variety as compared to other companion varieties. The LCC practice of nitrogen application which was worked out to be $93 \mathrm{~kg} \mathrm{ha}^{-1}$ is the most appropriate dose of $\mathrm{N}$ in rice crop which should be applied in splits. Moreover, the leaf color chart (LCC) is an easy-to use and inexpensive diagnostic tool for monitoring the relative greenness of a rice leaf as an indicator of the plant nitrogen status. The LCC can be used to guide the application of nitrogen fertilizer to maintain optimal leaf nitrogen content for achieving high rice yield with effective nitrogen management. Leaf color is generally used as a visual and subjective indicator of the rice crops need for nitrogen fertilizer. Leaf color intensity is directly related to leaf chlorophyll content and leaf nitrogen status. Leaf color chart is a tool that can help farmers improve their decision-making process in nitrogen management.

\section{Abbreviations}

LCC: Leaf color chart

NPK: Nitrogen, phosphorus, and potassium

LAI: Leaf Area Index

ARI: Agricultural Research Institute.

\section{Conflict of Interests}

The authors declare that there is no conflict of interests regarding the publication of this paper.

\section{Acknowledgment}

The authors are grateful to all the staff of Cereals section of Agricultural Research Institute Mingora Swat for their sincere cooperation and hard work to make this trial possible.

\section{References}

[1] T. D. Barai, A. Gazanchian, H. A. Pirdashti, and M. Nasiri, "Flag leaf morpho-physiological response to different agronomic treatments in promising line of rice (Oryza sativa L.)," American-Eurasian Journal of Agriculture \& Environmental Sciences, vol. 5, no. 3, pp. 403-408, 2009.

[2] M. Kubo and M. Purevdorj, "The future of rice production and consumption," Journal of Food Distribution \& Research, vol. 35, no. 1, pp. 128-142, 2004.

[3] Agricultural Statistics of Pakistan, MINFA (Ministry for Food \& Agriculture), Islamabad, Pakistan, 2010-2011.

[4] Crop Statistics of Khyber Pakhtunkhwa, Government of Khyber Pakhtunkhwa. Crop Reporting Services. Agriculture Livestock \& Cooperative Department, 2010.

[5] M. Nedunchezhiyan and K. Laxminarayan, "Site specific nutrient management for rice," Orissa Review, pp. 62-64, 2011.

[6] S. Peng, R. J. Buresh, J. Huang et al., "Improving nitrogen fertilization in rice by sitespecific N management. A review," Agronomy for Sustainable Development, vol. 30, no. 3, pp. 649656, 2010.

[7] C. Witt, J. M. C. A. Pasuquin, R. Mutters, and R. J. Buresh, "leaf color chart for effective nitrogen management in rice," Better Crops, vol. 89, pp. 36-39, 2005.

[8] M. M. Alam, J. K. Ladha, S. R. Khan et al., "Leaf color chart for managing nitrogen fertilizer in lowland rice in Bangladesh," Agronomy Journal, vol. 97, no. 3, pp. 949-959, 2005.

[9] D. K. Nath, F. Haque, F. Amin, M. S. H. Islam, and M. A. Saleque, "Farmers' participatory site specific nutrient management in gangetic tidal floodplain soil for high yielding Boro rice (Oryza sativa L.)," The Agriculturists, vol. 11, no. 1, pp. 8-14, 2013.

[10] S. Ravi, S. Ramesh, and B. Chandrasekaran, "Exploitation of hybrid vigour in rice hybrid (Oryza sativa L.) through green manure and Leaf Colour Chart (LCC) based N application," Asian Journal of Plant Sciences, vol. 6, no. 2, pp. 282-287, 2007.

[11] S. Krishnakumar and S. Haefele, "Integrated nutrient management and LCC based nitrogen management on soil fertility and yield of rice (Oryza sativa L.)," Scientific Research and Essays, vol. 8, no. 4, pp. 2059-2067, 2013.

[12] K. Sathiya and T. Ramesh, "Effect of split application of nitrogen on growth and yield of aerobic rice," Asian Journal of Experimental Sciences, vol. 23, no. 1, pp. 303-306, 2009.

[13] D. Salman, S. Morteza, Z. Dariush et al., "Application of nitrogen and silicon rates on morphological and chemical lodging related characteristics in rice (Oryza sativa L.) at North of Iran," Journal of Agricultural Science, vol. 4, no. 6, 2012.

[14] A. Doberman and T. Fairhurst, Rice: Nutrient Disorders \& Nutrient Management, IRRI, Makati, Philippines, 2000.

[15] S. Yoseftabar, "Effect of split application of nitrogen fertilizer on leaf color chart values in hybrid rice (GRH1)," International Journal of Biology, vol. 5, no. 1, pp. 79-84, 2012. 
[16] R. M. Kumar, K. Padmja, and S. V. Subbaiah, "Varietal response to different nitrogen management methods in an irrigated transplanted rice ecosystem in a Vertisol, Andhra Pradesh, India," International Rice Research Note, vol. 25, no. 2, pp. 3234, 2000.

[17] M. S. H. Islam, M. S. U. Bhuiya, S. Rahman, and M. Hussain, "Evaluation of SPAD and LCC based nitrogen management in rice (Orayza sativa L.)," Bangladesh Journal of Agriculture Research, vol. 34, no. 4, pp. 661-672, 2009. 

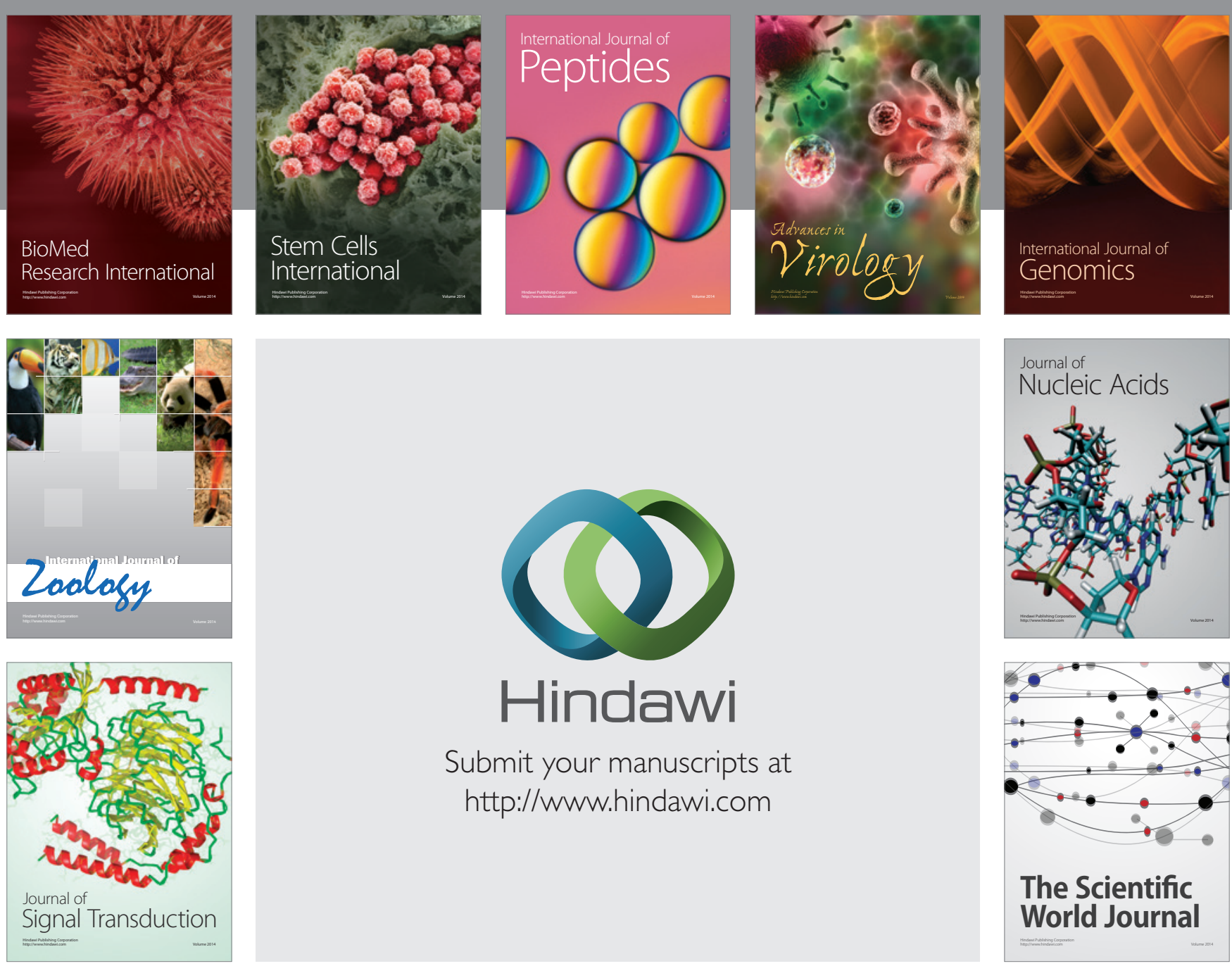

Submit your manuscripts at

http://www.hindawi.com
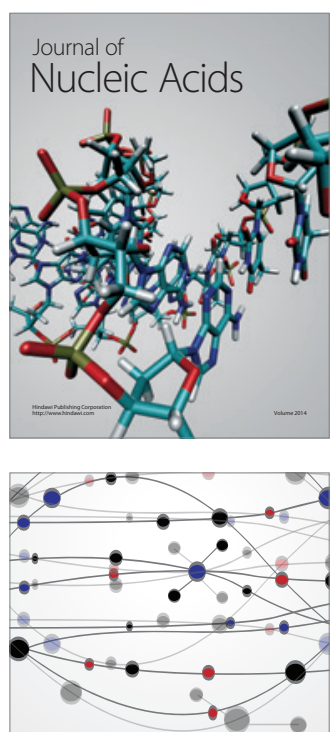

The Scientific World Journal
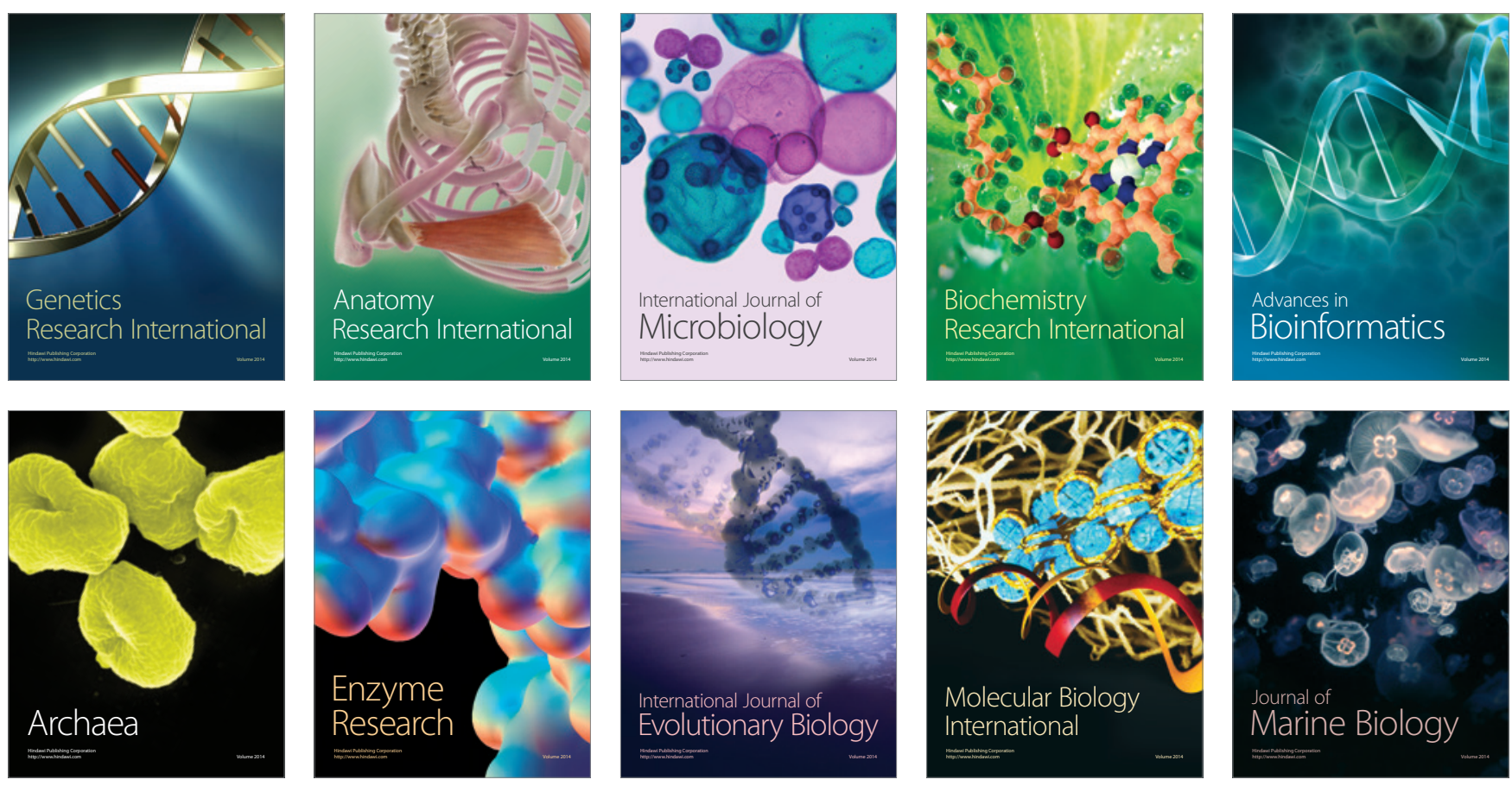